\title{
The effect of tax revenue budgeting errors on fiscal balance: evidence from the Swiss cantons
}

\author{
Florian Chatagny $\cdot$ Nils C. Soguel
}

Published online: 30 July 2011

(C) Springer Science+Business Media, LLC 2011

\begin{abstract}
This study is an empirical analysis of the impact of direct tax revenue budgeting errors on fiscal deficits. Using panel data from 26 Swiss cantons between 1980 and 2002, we estimate a single equation model on the fiscal balance, as well as a simultaneous equation model on revenue and expenditure. We use new data on budgeted and actual tax revenue to show that underestimating tax revenue significantly reduces fiscal deficits. Furthermore, we show that this effect is channeled through decreased expenditure. The effects of over and underestimation turn out to be symmetric.
\end{abstract}

Keywords Fiscal deficits - Tax revenue budgeting errors - Swiss cantons · Simultaneous equations model with panel data

JEL Classification $\mathrm{C} 12 \cdot \mathrm{C} 33 \cdot \mathrm{H} 71 \cdot \mathrm{H} 72$

\section{Introduction}

Over the past 40 years, most countries have experienced repeated public deficits and accumulated large public debts. Such changes in public deficits and public debt have

F. Chatagny $(\bowtie) \cdot$ N.C. Soguel

Swiss Graduate School of Public Administration, University of Lausanne, rte de la Maladière 21, 1022 Chavannes-près-Renens, Switzerland

e-mail: florian.chatagny @idheap.unil.ch

N.C. Soguel

e-mail: nsoguel@idheap.unil.ch

F. Chatagny

Department of Economics, University of Rennes 1, place Hoche 7, CS 86514, 35065 Rennes cedex, France

e-mail: florian.chatagny@univ-rennes1.fr 
varied widely between countries. ${ }^{1}$ Furthermore, subnational levels of government have not been immune to this phenomenon. ${ }^{2}$ In consequence, the theoretical and empirical literature devoted to better understanding the role of fiscal deficits and debt accumulation has flourished. Moreover, the current crisis of public finances in some European countries highlights the need for improved understanding of the determinants driving fiscal deficits and debt accumulation.

By emphasising the role played by tax revenue budgeting errors in the determination of fiscal outcomes, the current empirical analysis contributes to the literature on determinants of fiscal deficits and builds a bridge to the currently blossoming empirical literature on tax revenue predictions. This latter stream of literature actually provides insights into the effect of tax revenue budgeting errors on fiscal deficits. In their empirical analysis of tax revenue projections in Flemish municipalities, Goeminne et al. (2008) recently suggested, without testing it explicitly, that revenue forecasts can be used as a tool to prevent excessive deficits. In this paper, our objective is to test for this effect. Furthermore, if an effect of tax revenue budgeting errors on deficits is observed, we argue that it is channeled through a reduction in expenditure. Indeed, underestimating future tax revenue may be used to put pressure on expenditure and to curb politicians' financial appetite, thereby decreasing deficits.

Using panel data from 26 Swiss cantons over the 1980-2002 period, we estimate the ceteris paribus effect of tax revenue budgeting errors on deficits with a single equation model of fiscal deficits and with a simultaneous equations model of revenue and expenditure by two-stage and three-stage least squares, respectively. First, our estimations show that underestimating tax revenue significantly reduces fiscal deficits. Then we demonstrate that this effect is clearly channeled through a decrease in expenditure. Finally, we also find that under and overestimation affect deficits in a symmetric way. These results are robust to different estimation procedures.

The remainder of the paper is organized as follows. In the next section, we provide a discussion of the literature related to our research and present the hypothesis we intend to test empirically. In Sect. 3, we present the dataset on Swiss cantons used to test our hypothesis. Section 4 is devoted to the econometric models and the estimators used, as well as to the main results obtained. In Sect. 5, we discuss the results and conclude.

\section{Related literature and testable hypothesis}

The current empirical analysis is a study of the relationship between tax revenue budgeting errors and fiscal outcome. It lies at the crossroad of two areas of research. First, it is a contribution to the traditional literature on the determinants of fiscal deficits and

\footnotetext{
${ }^{1}$ For example, while the debt to GDP ratio increased from $14.10 \%$ to $103.15 \%$ in Greece over the $1965-$ 2007 period, it increased only from $30.50 \%$ to $48.05 \%$ in Sweden during the same period. Source: OECD.

${ }^{2}$ At the subnational government level in Switzerland, while the level of debt per capita ranged from 1,697 to $11,238 \mathrm{CHF}$ in 1980 , it rose to a range of 2,457 to $41,851 \mathrm{CHF}$ in 2002.
} 
debt. Beyond the well-known normative models of tax smoothing and stabilization policy, there exist numerous positive approaches concerning budget deficits and public debt. ${ }^{3}$ Among the latter, some authors (e.g., von Hagen and Harden 1995; Poterba 1996, or Alesina and Perotti 1999) have emphasized the role played by budgetary institutions, among which is the tax revenue budgeting process. On the one hand, some authors argue that incumbent politicians may have the incentive to manipulate public budgets in order to achieve their own objectives. In particular, Alesina and Perotti (1999) suggest that in practice politicians may deliberately overestimate tax revenue, thereby creating higher deficits. This strategy allows politicians to attribute deficits to the technical difficulty in predicting future revenue. On the other hand and more recently, van der Ploeg (2010) has theoretically showed that deliberately underestimating the tax base may be desirable to curb spending ministers' financial appetites, and to reduce debt. By setting a higher tax rate and lower level of public spending, the government builds a precautionary buffer against future shocks, reducing debt in this way. In the current study, we argue that such buffer may be created by underestimating and underbudgeting tax revenue in order to put pressure on expenditure, and subsequently to create a revenue windfall, thereby reducing the deficit. However, the creation of a precautionary buffer may be subsequently used to increase expenditure in an election year (Bischoff and Gohout 2010; van der Ploeg 2010). Thus, the prudent budgeting of tax revenue does not guarantee to result in reduced deficits and debt. In the current research, we therefore propose to test empirically whether underestimating tax revenue actually results in lower deficits.

We then also go on to extend the currently flourishing empirical literature on tax revenue prediction errors. In 1989, Feenberg et al. applied rational expectations theory to develop a rigorous econometric framework that makes it possible to test the rationality of tax revenue predictions. Some authors have applied this method to national and subnational jurisdictions and have shown that conditions for rational predictions fail most of the time (see, for example, Feenberg et al. 1989; Mocan and Azad 1995; Auerbach 1999). This appealed to some with more positive approaches to trying to understand the determinants of tax revenue prediction errors. ${ }^{4}$ Most of these studies take the fact that tax revenue budgeting errors affect fiscal balance for granted, without ever testing it explicitly. Nonetheless, they provide some evidence on what type of tax revenue budgeting errors are empirically observed and some perspectives on how it may affect fiscal balance.

Among most recent studies, Bischoff and Gohout (2010) show that West German states tend to (weakly) overestimate their tax revenue projections. They argue that incumbent politicians in state governments may do so in order to increase expenditure - thereby increasing deficit—and eventually their reelection prospects. Conversely, Goeminne et al. (2008) have recently argued that prudent revenue fore-

\footnotetext{
${ }^{3}$ According to Alesina and Perotti (1995) and Pinho (2004), theoretical budget deficit models can be classified by different categories: models of the political business cycle with fiscal illusion (Nordhaus 1975), partisan cycles theory (Hibbs 1987), models of debt used as a strategic tool by incumbent policy makers (Persson and Svensson 1989), models of redistribution conflicts and models of conflict between political parties (Roubini and Sachs 1989).
}

${ }^{4}$ For an extensive review of this literature, see Goeminne et al. (2008) and Couture and Imbeau (2009). 
casts may be used as a tool to prevent excessive deficits. Indeed, they provide an empirical analysis of the relationship between political fragmentation and tax revenue budgeting errors, using data on Flemish municipalities. Although their data also exhibit a tendency of Flemish municipalities to (slightly) overestimate tax revenue, they show that coalition governments-with at least three parties in power-tend to overestimate tax revenue less than single-party and two-party coalitions-whereas Bischoff and Gohout do not find any significance for the coalition variable. ${ }^{5}$ Comparing their results to what Serritzlew found in the Danish case, ${ }^{6}$ Goeminne et al. (2008, p. 311) conclude that "to the extent that there is indeed a systematic relation between revenue forecasting behaviour and public debts (or deficits), this should translate into a better financial performance of highly fragmented governments in the Danish setting (much like the one observed here for Flanders). As such results are not provided in Serritzlew (2005), it is left to future research in the field to assess the extent to which our results - and the ensuing alternative explanation for government debts and deficits-generalise over different settings, or what drives possible deviations." The main result found and the conclusion drawn by Goeminne et al. are of direct interest for the present study. First, while in the Flemish case the occurrence of coalition governments is increasing over time and becoming more prevalent, data on Swiss cantons show that coalitions are the rule and single party governments the exception. ${ }^{7}$ In addition, data show that Swiss cantons turn out to be very cautious in the way they predict tax revenue since, on average, underestimated tax revenue is observed (see Table 1). Unlike Goeminne et al., we do not test the relationship between fragmentation and prediction errors explicitly; however, the Swiss case offers an ideal setting to extend Goeminne et al. work and to test part of what they suggest in their conclusion, which is to say: (1) to test whether prudent tax revenue prediction translates into a better financial performance of highly fragmented governments and (2) to test whether this relationship generalizes over different settings in our case Swiss cantons. Thus, in a more concise formulation, we propose to empirically test the following hypothesis.

Hypothesis By reducing expenditure, underestimating tax revenue decreases fiscal deficits.

The above hypothesis states a negative relationship between tax revenue underestimation and fiscal deficits, which will be assessed by econometric methods using data from the Swiss cantons. Before presenting the data and methodology in more detail, we note that the above expressed hypothesis begins with: By reducing expenditure. Indeed, in addition to arguing that prudent tax revenue budgeting decreases

\footnotetext{
${ }^{5}$ Goeminne et al. find a nonlinear effect of coalitions on tax revenue projection. While two party coalitions tend to be more optimistic about their forecast, governments with at least three parties turn out to be more cautious.

${ }^{6}$ Serritzlew (2005) provides an empirical analysis of budget overruns in Danish municipalities.

${ }^{7}$ Data on Swiss cantons show that coalitions with at least two parties in power occur in more that $95 \%$ of the cases. Coalitions with at least three parties occur in more than $75 \%$ of the cases.
} 
Table 1 Tax revenue budgeting errors in the Swiss cantons (1980-2002)

\begin{tabular}{|c|c|c|c|c|}
\hline & Mean & sd & $\min$ & $\max$ \\
\hline Bern (BE) & 33.097750 & 79.94247 & -130.4519 & 195.3134 \\
\hline Schaffhausen (SH) & -6.058505 & 70.88950 & -101.9767 & 167.774 \\
\hline Appenzell Ausserrhoden (AR) & -21.16736 & 55.66625 & -95.56966 & 122.1079 \\
\hline Uri (UR) & -21.22310 & 134.0090 & -296.4199 & 236.6541 \\
\hline Solothurn (SO) & -23.16581 & 127.6487 & -225.1344 & 294.9495 \\
\hline Jura (JU) & -24.60964 & 60.33362 & -139.0612 & 64.00689 \\
\hline Thurgau (TG) & -28.76536 & 83.43697 & -183.1832 & 142.6931 \\
\hline Sankt-Gallen (SG) & -28.89539 & 67.30484 & -167.4951 & 151.4163 \\
\hline Zürich (ZH) & -33.04345 & 144.7140 & -432.4096 & 174.6628 \\
\hline Neuchâtel (NE) & -37.46447 & 100.5035 & -199.5525 & 216.8463 \\
\hline Obwald (OW) & -39.71332 & 83.81209 & -193.8892 & 178.6296 \\
\hline Aargau (AG) & -41.95892 & 108.9408 & -233.4848 & 195.3342 \\
\hline Luzern (LU) & -45.38220 & 86.22625 & -239.8802 & 62.91078 \\
\hline Valais (VS) & -62.84744 & 93.46271 & -243.8814 & 183.7683 \\
\hline Nidwald (NW) & -65.19043 & 115.7389 & -538.5290 & 39.08583 \\
\hline Vaud (VD) & -66.60113 & 147.1721 & -278.4558 & 290.3864 \\
\hline Graubünden (GR) & -80.89374 & 56.41266 & -188.2635 & 45.78116 \\
\hline Fribourg (FR) & -85.30994 & 72.98334 & -230.3515 & 63.86345 \\
\hline Genève (GE) & -94.37503 & 401.0994 & -1167.721 & 602.6343 \\
\hline Schwyz (SZ) & -95.57028 & 69.48521 & -260.0174 & 82.54814 \\
\hline Baselland (BL) & -98.26155 & 144.4911 & -433.2656 & 150.8883 \\
\hline Baselstadt (BS) & -102.2706 & 411.8105 & -1035.104 & 545.078 \\
\hline Appenzell Innerrhoden (AI) & -117.9050 & 109.2565 & -344.7328 & 99.05705 \\
\hline Glarus (GL) & -144.8706 & 174.0521 & -415.2252 & 107.9505 \\
\hline Ticino (TI) & -170.8208 & 214.3000 & -574.9767 & 265.8552 \\
\hline $\mathrm{Zug}(\mathrm{ZG})$ & -235.1116 & 165.5196 & -569.8398 & 8.026999 \\
\hline All & -66.73260 & 163.9699 & -1167.721 & 602.6343 \\
\hline
\end{tabular}

deficits, we tend to think that this effect (if observed) is mainly channeled through reduction in expenditure. This argument is in line with budgetary practices observed in the Swiss cantons where tax revenue is initially determined, and budget allowance for expenditure is then allocated accordingly. Furthermore, this idea seems to be supported by authors of other empirical studies who think that revenue prediction errors have a direct effect on expenditure. For instance, while Bischoff and Gohout (2010, p. 133) state that "... biased tax projections help governments to bring forward favorable expenditures and to burden their successors," Goeminne et al. (2008, p. 310) mention that "They [broad-based coalitions] might thus be less prone to threats of minor interest groups, limiting increases in expenditures and thereby the need to present 
optimistic budgets." To the extend that this might hold for Flemish municipalities, we are inclined to think that this is the case for the Swiss cantons as well, and we propose to test this hypothesis explicitly. Data used to carry out such tests are presented in the next section.

\section{Data}

To test the hypothesis presented in Sect. 2, we rely on panel data from the 26 Swiss cantons between 1980 and 2002. ${ }^{8}$ This database contains data on revenue and expenditure and a complete set of explanatory variables that are usually encountered in empirical studies on fiscal deficits. Our main explanatory variable is drawn from a new database that contains actual and budgeted tax revenue in the 26 cantons over the 1980-2002 period.

\subsection{Tax revenue budgeting errors}

To test our hypothesis empirically, we need to choose an appropriate measure of tax revenue budgeting errors. In the literature treating tax revenue forecasting accuracy, ${ }^{9}$ absolute errors are often used as an indicator in order to avoid positive and negative errors that offset each other. In this paper, however, we want precisely to obtain information about the sign of the budgeting error. Thus, as the numerator of our indicator, we chose the difference between the budgeted amount of tax revenue and the actual amount. Since variables in our model will be expressed in per capita terms, the cantonal population has been chosen as the denominator. This specification allows us to make tax revenue budgeting errors comparable between cantons. Our indicator measuring tax revenue budgeting errors may be expressed as follows:

$$
\text { Error }=\frac{\left(R_{b}-R_{a}\right)}{P}
$$

where $R$ denotes direct tax revenue, the subscript $a$ stands for actual, the subscript $b$ stands for budgeted, and $P$ denotes the cantonal population. To compute this indicator, we collected budgeted and actual revenue that are reported in public accounts of Swiss cantons over the period. ${ }^{10}$ The usual summary statistics are reported in Table 1.

In Table 1, the cantons are ranked according to their mean budgeting error. This ranking shows that all but one of the cantons $(\mathrm{BE})$ have tax revenue budgeting er-

\footnotetext{
${ }^{8}$ The choice of this time span is justified as follows: we start in 1980 because in 1979 the last Swiss canton (JU) was created by partition from the canton of Bern, thereby rendering the sample of cantons before and after 1979 incomparable. Then we stop in 2002 because the database of control variables is incomplete for subsequent years.

${ }^{9}$ See, for example, Mocan and Azad (1995), p. 419.

${ }^{10}$ Between 1945 and 2007 and over the 1980-2002 period of interest, public accounts do not distinguish between personal and corporate tax revenue for every canton and/or every time span. For this reason, we used what we call "direct taxes," i.e., the addition of both personal and corporate taxes. The use of this aggregate enables us to exploit a complete and homogenous dataset across both cantons and years.
} 
rors below zero on the average. Thus, we clearly observe a tendency to underestimate tax revenue. T-tests performed on the mean show that tax revenue budgeting errors are systematically and significantly underestimated in the majority of cantons, and in Swiss cantons as a whole. We note further that, with an average error per capita ranging from 33,098 Swiss francs (CHF) for Bern (BE) to $-235,112 \mathrm{CHF}$ for $\mathrm{Zug}(\mathrm{ZG})$, tax revenue budgeting errors exhibit strong heterogeneity among cantons. Moreover, standard deviations suggest that tax revenue budgeting errors also have strong intertemporal variability. In consequence, variability in budgeting errors can be exploited to try to quantify their potential effect on fiscal deficits. In this respect, the interesting question that arises is: do cantons also exhibit strong differences in terms of fiscal deficits (per capita) on the average? The next subsection shows that this is in fact the case.

\subsection{Fiscal balances}

To estimate the marginal effect of tax revenue budgeting errors on fiscal deficits, we need to measure the latter variable. In this study, we define fiscal balance as the difference between revenue and expenditure, and we use the data for cantonal revenues and expenditure that are computed and provided by the Federal Department of Finance. Table 2 presents summary statistics for cantonal deficits per capita over the 19802002 period. ${ }^{11}$ As in the case of budgeting errors, cantons are ranked according to their mean.

First, we note that over the period considered, Geneva (GE) has a deficit which is more than twice as large as the canton that has the second largest deficit on the average, which is the canton of Vaud (VD). This difference justifies the inclusion of a dummy variable for this canton in the set of control variables (see Sect. 3.3). Similar to what is observed for average budgeting errors, deficits exhibit considerable heterogeneity among cantons, ranging from $-734 \mathrm{CHF}$ per capita for GE to $123 \mathrm{CHF}$ per capita for AI. We can see that some cantons such AI, SZ, or ZG, which have generated surpluses on the average, belong to the cantons that are substantially underestimating their tax revenue. Conversely, the reverse observation cannot be made. Thus, a mere glance at summary statistics is insufficient to draw clear-cut conclusions about the correlation between tax revenue budgeting errors and public deficits. To do so, more rigorous econometric tools are required.

\subsection{Control variables}

In order to isolate precisely the effect of our variable of interest (Error), we need to control for the effect of other variables on cantonal deficits. In line with previous work on fiscal deficits, we control for the growth rate of cantonal incomes (as a proxy for GDP growth) and the unemployment rate (see, e.g., Kirchgässner and Pommerehne 1997). We also include potentially important political determinants of deficits such

\footnotetext{
${ }^{11}$ For measures of revenue and expenditure, we use the separated series from the Federal Department of Finance. Summary statistics are provided in Appendix A.
} 
Table 2 Fiscal balances in the Swiss cantons (1980-2002)

\begin{tabular}{|c|c|c|c|c|}
\hline Canton & Mean & sd & $\min$ & $\max$ \\
\hline Genève (GE) & -734.3611 & 826.8167 & -2513.386 & 607.9089 \\
\hline Vaud (VD) & -305.3086 & 436.913 & -1134.335 & 284.1735 \\
\hline Jura (JU) & -269.7521 & 263.4787 & -660.1033 & 284.8849 \\
\hline Neuchâtel (NE) & -244.673 & 332.3113 & -1045.022 & 142.7332 \\
\hline Baselstadt (BS) & -230.4947 & 798.2137 & -1854.755 & 1296.544 \\
\hline Bern (BE) & -196.5969 & 318.0202 & -803.3543 & 353.4736 \\
\hline Appenzell Ausserrhoden (AR) & -141.0955 & 301.8264 & -711.6563 & 355.0611 \\
\hline Zürich $(\mathrm{ZH})$ & -129.0238 & 431.273 & -809.0168 & 825.5766 \\
\hline Glarus (GL) & -124.8607 & 389.5551 & -1309.669 & 452.2523 \\
\hline Valais (VS) & -109.7136 & 277.2125 & -635.4553 & 448.3997 \\
\hline Luzern (LU) & -103.6451 & 325.0108 & -607.4554 & 596.7086 \\
\hline Thurgau (TG) & -89.79546 & 284.568 & -585.5226 & 454.0573 \\
\hline Uri (UR) & -84.70413 & 526.7713 & -1111.767 & 1067.085 \\
\hline Solothurn (SO) & -78.21859 & 247.6831 & -634.895 & 239.3287 \\
\hline Obwalden (OW) & -32.73404 & 312.3124 & -610.627 & 733.8257 \\
\hline Sankt-Gallen (SG) & -10.30338 & 194.1256 & -389.1809 & 275.0618 \\
\hline Graubünden (GR) & 11.15879 & 247.7473 & -362.364 & 444.9858 \\
\hline Ticino (TI) & 16.02092 & 474.9252 & -768.3969 & 906.9489 \\
\hline Schaffhausen (SH) & 21.86632 & 230.7747 & -546.6951 & 335.9798 \\
\hline Nidwalden (NW) & 31.23354 & 289.6734 & -456.059 & 724.5751 \\
\hline Aargau (AG) & 38.08353 & 169.1206 & -346.9848 & 321.304 \\
\hline Fribourg (FR) & 41.48465 & 338.358 & -835.9874 & 613.8598 \\
\hline Baselland (BL) & 46.04834 & 343.6327 & -683.9509 & 616.8721 \\
\hline Zug (ZG) & 86.92754 & 642.557 & -1433.325 & 1219.716 \\
\hline Schwyz (SZ) & 121.7364 & 325.1743 & -263.8192 & 1071.407 \\
\hline Appenzell Innerrhoden (AI) & 123.3337 & 262.6828 & -288.4537 & 634.8669 \\
\hline All & -90.28412 & 431.5964 & -2513.386 & 1296.544 \\
\hline
\end{tabular}

as the political leaning of the government measured by the proportion of right-wing members among cantonal executives (cf. Hibbs 1987), ${ }^{12}$ political concordance (see Niskanen 1971 and Velasco 2000) measured by the percentage of the seats in the legislature that are occupied by members of parties represented in the executive, an election dummy equal to 1 for the years when elections are held and zero otherwise (cf. Nordhaus 1975), and the number of Spending Ministers measured by the number of departments in the cantonal administration as a proxy (see Velasco 2000; Wehner 2010). We also include an indicator of political fragmentation measured by the number of parties in the government cabinet (see, e.g., Roubini and Sachs 1989;

${ }^{12}$ This variable is used as a proxy for voters' fiscal preferences. 
Ashworth et al. 2005, or Wehner 2010). ${ }^{13}$ To control for institutional determinants of deficits, we include categorical variables measuring the stringency of referendums and initiatives (using the indices devised by Frey and Stutzer 2005). In some cases, institutions turn out to be endogenous in the sense that they are themselves influenced by fiscal variables. ${ }^{14}$ To control for this endogeneity problem, we instrumented the referendum and initiative variables using their lagged values (Matsusaka 1995; Feld and Matsusaka 2003). We also include several structural variables such as the age structure of the population ${ }^{15}$ measured by the rate of elderly in the cantonal populations (see, e.g., Feld and Matsusaka 2003; Garand and Kapeluck 2004) or a dummy variable for the canton of Geneva. ${ }^{16}$ Finally, to take into account the fact that revenue and expenditure do not fully adjust from year to year and exhibit inertia, we include lagged values of dependent variables as explanatory variables. This procedure also has the advantage of removing autocorrelation from the series. In the following section, we describe how the above data are used to test our hypothesis, and we present our main findings.

\section{Empirical analysis}

To test the hypothesis formulated in Sect. 2, we use two complementary approaches: direct modeling of the fiscal deficit (surplus), and modeling through a system of two equations, one for expenditure and one for revenue.

\subsection{Single equation model: methodology and results}

The first approach consists of estimating the effect of tax revenue budgeting errors directly on fiscal balance. Such a model considers fiscal deficit or surplus as the explained variable and can be expressed as follows:

$$
B_{i t}=\alpha+\text { Error }_{i t}^{\prime} \mu+X_{t} \delta+\epsilon_{i t}
$$

where $i$ and $t$ are the subscripts for the individual canton and time period, respectively, $B$ denotes fiscal balance, $\alpha$ is the constant term, Error denotes our variable of interest and $\mu$ its associated coefficient, $X$ is a vector of control variables and $\delta$ its corresponding vector of coefficients, and $\epsilon$ is the error term. ${ }^{17}$ Given that Error

\footnotetext{
${ }^{13}$ This is the variable called COALITION in Appendix A.

${ }^{14}$ For a discussion, see Alesina and Perotti (1999), p. 14.

${ }^{15}$ Note that we also use the average population in the cantons not as an explanatory variable, but in order to express some variables in per capita terms. Doing so, allows us to wash out size effects and to reduce heterogeneity.

${ }^{16}$ This is a common practice in empirical studies on Swiss cantons. For instance, Pommerehne et al. (1996) include such a variable in their study of tax harmonization and tax competition in the Swiss cantons. Geneva is known to be quite different fiscally from other cantons and to be, by far, the most spendthrift Swiss canton, with much higher deficits than the others (see Table 2).

${ }^{17}$ Although it would theoretically make sense to expect $\mu$ to vary among cantons, the small number of periods observed (22) does not allow us to estimate a SUR model consistently. Thus, $\mu$ does not have $i$ subscripts.
} 
is a variable that assumes negative values when tax revenue are underestimated, we expect to find a value of $\hat{\mu}$ that is significantly different from zero and negative. This would mean that underestimating tax revenue increases fiscal surpluses and decreases fiscal deficits, respectively.

To provide a good estimate of $\mu$ and to make correct inferential statements, it is necessary to take into account several characteristics of our model. First, let us point out that Swiss cantons are very heterogenous in terms of budget size. Thus, although heterogeneity can be partially reduced by expressing our model in per capita terms, $\epsilon$ still exhibits strong heteroscedasticity. Then, given the variables included in $X_{t},{ }^{18}$ some endogeneity problems arise. Since $E\left[X_{t} \epsilon_{i t}\right]=0$ does not hold, the OLS estimator will no longer be unbiased and consistent. Finally, in most of the cantons, time series exhibit AR(1) autocorrelation. In order to remove autocorrelation and also because it theoretically and empirically makes sense, we include a lagged dependent variable in $X_{t}$.

To estimate our econometric model consistently, the literature usually recommends the use of difference GMM (Arellano and Bond 1991) or of system GMM (Arellano and Bover 1995; Blundell and Bond 1998). For instance, Goeminne et al. use a system GMM type of estimator in their empirical analysis on Flemish municipalities. However, given the nature of our data, this method may not be the most appropriate approach. Indeed, several regressors in $X_{t}$ are almost time-invariant. Since GMM estimators for panel data explicitly model individual effects, parameter estimates tend to be inflated because of the high degree of collinearity between the timeinvariant variables and the fixed effects. ${ }^{19}$ Thus, since unit heterogeneity is already captured by the time-invariant regressors, we used an instrumental variables approach and estimated the model by two-stage least squares (2SLS). We instrumented referendum and initiative with their lagged value. ${ }^{20}$ Remaining heteroscedasticity is handled through the White correction for standard errors.

Estimation results from the single equation model of fiscal deficits are reported in Table 3. First, we note globally that although some of the control variables are individually not significant, joint tests of significance (row "Joint") show that the coefficients are jointly significant. Column (2) reports the estimate obtained using two-stage least squares (2SLS). ${ }^{21}$ It shows that the parameter associated with the tax revenue budgeting error indicator is strongly significant. Furthermore, as expected, the coefficient has a negative value. Given that our indicator of Error assumes a negative value when tax revenue is underestimated, this result means that

\footnotetext{
${ }^{18}$ The explanatory variables referendum and initiative are considered as endogenous to the model (see Sect. 3.3).

${ }^{19}$ Random effects are inappropriate in our case since we analyse the full sample and not a random draw from the population.

${ }^{20}$ In the case where autocorrelation had not been completely removed by the lagged dependent variable, this condition would cause the lagged dependent variable to be endogenous to the model as well. To check the robustness of our results with respect to this case, we also instrumented alternatively the lagged dependent variable with its lagged value. Results turned out to be robust.

${ }^{21}$ This column reports the estimates obtained using the 2SLS estimator without instrumenting the lagged dependent variable (NILDV).
} 
Table 3 Single equation estimation: results

\begin{tabular}{|c|c|c|c|}
\hline & $(1)$ & (2) & (3) \\
\hline & GMM & 2SLS & 2SLS \\
\hline & & NILDV & ILDV \\
\hline \multirow[t]{2}{*}{ Error } & $-0.857^{* * *}$ & $-0.767^{* * *}$ & $-0.785^{* * *}$ \\
\hline & $(0.0704)$ & $(0.0780)$ & $(0.0823)$ \\
\hline \multirow[t]{2}{*}{ Balance $(-1)$} & $0.595^{* * *}$ & $0.586^{* * *}$ & $0.513^{* * *}$ \\
\hline & $(0.0283)$ & $(0.0352)$ & $(0.0569)$ \\
\hline \multirow[t]{2}{*}{ Initiative } & 25.28 & -11.29 & -12.30 \\
\hline & (27.99) & (12.13) & $(12.97)$ \\
\hline \multirow[t]{2}{*}{ Growth } & $38.82^{* * *}$ & $31.78^{* * *}$ & $38.84^{* * *}$ \\
\hline & $(6.820)$ & $(6.741)$ & $(7.415)$ \\
\hline \multirow[t]{2}{*}{ Unemployment } & 9.617 & 2.486 & -6.745 \\
\hline & $(8.140)$ & $(8.048)$ & $(8.514)$ \\
\hline \multirow[t]{2}{*}{ Referendum } & 2.096 & $26.25^{* *}$ & $27.12^{* *}$ \\
\hline & (19.61) & $(9.430)$ & $(10.45)$ \\
\hline \multirow[t]{2}{*}{ Concordance } & $5.106^{* *}$ & 1.261 & 1.247 \\
\hline & $(1.774)$ & $(1.382)$ & $(1.436)$ \\
\hline \multirow[t]{2}{*}{ Elderly } & -4.300 & -6.987 & -7.752 \\
\hline & $(12.47)$ & $(6.662)$ & $(6.908)$ \\
\hline \multirow[t]{2}{*}{ Right-wing } & 0.363 & 0.156 & 0.0763 \\
\hline & $(1.513)$ & $(0.958)$ & (1.024) \\
\hline \multirow[t]{2}{*}{ Coalition } & -11.05 & -25.97 & -28.65 \\
\hline & $(32.73)$ & (14.49) & $(15.06)$ \\
\hline \multirow[t]{2}{*}{ Departments } & -13.85 & $-11.72^{*}$ & $-13.80^{* *}$ \\
\hline & $(9.414)$ & $(4.956)$ & $(5.126)$ \\
\hline \multirow[t]{2}{*}{ Election } & -19.32 & -22.26 & -15.74 \\
\hline & $(25.88)$ & $(28.35)$ & $(29.38)$ \\
\hline \multirow[t]{2}{*}{ Geneva } & & $-251.1^{* *}$ & $-289.3^{* * *}$ \\
\hline & & (84.19) & $(87.17)$ \\
\hline \multirow[t]{2}{*}{ Intercept } & -552.2 & -28.34 & 18.85 \\
\hline & $(320.8)$ & $(163.0)$ & $(172.5)$ \\
\hline$R^{2}$ & & 0.642 & 0.641 \\
\hline Joint & 0.0000 & 0.0000 & 0.0000 \\
\hline$N$ & 571 & 595 & 570 \\
\hline
\end{tabular}

Note: Parameter values appear without parentheses, and standard errors within. Asterisks denote the level of significance of parameter values: ****indicating significance at the $1 \%$ level, ${ }^{* *}$ at the $5 \%$ level, and ${ }^{*}$ at the $10 \%$ level. The Joint statistic tests the hypothesis that all coefficients are jointly equal to zero using the F-test or Chi-squared tests 
underestimating tax revenue increases fiscal surpluses or decreases deficits. When the per capita tax revenue budgeting error is underestimated by one additional Swiss franc, fiscal surplus (deficit) per capita increases (decreases) by about $0.77 \mathrm{CHF}$. One may wonder whether under and overestimation have an impact on fiscal balance of the same amplitude. We have formally tested this issue and found that the effect is statistically symmetrical. ${ }^{22}$ To check for the robustness of our results, we estimated our model using alternative estimators. Among others, we report, in column (1), the results obtained using system GMM since it is prevalent in the literature. Results turn out to be robust. ${ }^{23}$ However, due to high collinearity, some parameters tend to be inflated. Thus, 2 SLS provides a more accurate estimate. Finally, in column (3), we report the estimate obtained from 2SLS when we also instrument the endogenous lagged variable. Again, our results are robust, and the value of our parameter of interest is only marginally affected. While the direct approach using a single equation model allows one to isolate the effect of tax revenue budgeting errors on fiscal balance, it has the drawback of not showing the impact on expenditure that eventually determines the effect on fiscal balance. Consequently, adopting a simultaneous estimation of expenditure and revenue enables us to overcome this limitation.

\subsection{Simultaneous equations model: methodology and results}

By definition, fiscal balance $(B)$ is determined by revenue $(R)$ and expenditure $(E)$. Thus, fiscal balance can be modeled using two equations, one for revenue and the other for expenditure, as follows:

$$
\begin{aligned}
& R_{i t}=\alpha_{R}+\gamma_{R} E_{i t}+W_{t} \beta^{R}+\epsilon_{i t}^{R}, \\
& E_{i t}=\alpha_{E}+\text { Error }_{i t}^{\prime} \mu_{E}+\gamma_{E} R_{i t}+Z_{t} \beta^{E}+\epsilon_{i t}^{E}
\end{aligned}
$$

where $R$ denotes revenue, $E$ denotes expenditure, $\alpha_{R}$ and $\alpha_{E}$ are the intercepts, $\gamma$ measures the marginal effect of expenditure (revenue) on revenue (expenditure), $W_{t}$ and $Z_{t}$ are the sets of control variables explaining revenue and expenditure, respectively, with $\beta^{R}$ and $\beta^{E}$ the associated vectors of coefficients. Although they include the same set of control variables, $W_{t}$ and $Z_{t}$ are still different since they each include the lagged dependent variable of their respective equations. Finally, $\epsilon^{R}$ and $\epsilon^{E}$ denote the error terms.

This simultaneous equations model enables us to distinguish the respective determinants of revenue and expenditure that eventually affect fiscal balance. According to our hypothesis, we expect tax revenue budgeting errors to affect expenditure. Therefore, the variable Error and its associated coefficient $\mu$ appear on the right-hand side of (4). Assuming that Error is a variable that takes on a negative value when tax

\footnotetext{
${ }^{22}$ The results of the tests for symmetry are reported in Appendix C. These test results are robust to different estimation strategies and over both models.

${ }^{23}$ The dummy variable for Geneva does not appear since it is already accounted for by fixed effects. Its inclusion would be redundant.
} 
revenues are underestimated, we expect $\hat{\mu}_{E}$ to be significantly positive. This result would mean that underestimating tax revenue reduces expenditure, and subsequently increases surpluses or decreases deficits.

To produce consistent estimates of the parameters, and especially of $\hat{\mu}_{E}$, we took into account the different characteristics of our model. As for the single equation case, heteroscedasticity is treated using White correction for standard errors. As in the previous model, some regressors in $W_{t}$ and $Z_{t}$ are correlated with $\epsilon_{i t}$. Furthermore, as $R$ and $E$ are simultaneously determined, they are endogenous to the system, and we have $E\left[R_{i t} \epsilon_{i t}^{E}\right] \neq 0$ and $E\left[E_{i t} \epsilon_{i t}^{R}\right] \neq 0$. Subsequently, the existence of endogeneity necessitates the use of an estimator of the IV class. Given that we now have a system of two simultaneous equations, $E\left[\epsilon_{i t}^{R} \epsilon_{i t}^{E}\right]=0$ does not hold, and an estimator is required that also takes into account the correlation between error terms. Since the set of instruments is the same across equations, we chose the three-stage least squares estimator to estimate our parameters (Hayashi 2000).

Estimates for the simultaneous equations model are reported in Table $4 .{ }^{24}$ In particular, the estimation of the expenditure equation shows that the coefficient associated with tax revenue budgeting error is strongly significant. Furthermore, it has a positive value. This result indicates that underestimating tax revenue notably reduces expenditure. When tax revenue is underestimated by 1 additional $\mathrm{CHF}$, expenditure per capita decreases by about $0.47 \mathrm{CHF}$. From the parameter estimates in columns (1) and (2), we can recover the parameters of a hypothetical underlying single equation model by computing the parameters of the reduced form of the system. ${ }^{25}$ As for the coefficient of tax revenue budgeting errors, it indicates an estimate of about $-0.47 \mathrm{CHF}$ since the effect of expenditure on revenue is not significant. Although this roughly corroborates the single equation model, we can be confident that this measure of the effect of tax revenue budgeting errors on fiscal deficit is more precise because the simultaneous equations model allows us to partial out the effects of the control variables on expenditure and revenue more precisely. As in the single equation model, the effect of under- and overestimation on expenditure turns out to be symmetrical. ${ }^{26}$ As expected, our results provide some evidence that, if tax revenue budgeting errors have an impact on fiscal deficits, this impact is channeled through a reduction in expenditure.

\section{Conclusion}

Contributing to the literature on the determinants of fiscal deficits and extending Goeminne et al. empirical study on tax revenue projections, the present study pro-

\footnotetext{
${ }^{24}$ As for the single equation model, we estimated the simultaneous equations model once with an instrumented lagged dependent variables, column (2), and once without, column (1). Results turned out to be robust.

${ }^{25}$ The reduced form of the simultaneous equations model expresses expenditure and revenue only in terms of exogenous variables.

${ }^{26}$ See Appendix C, columns (1) and (2) under simultaneous equations.
} 
Table 4 Simultaneous equations estimation (3SLS): results

\begin{tabular}{|c|c|c|c|c|}
\hline \multirow{2}{*}{ 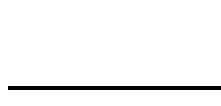 } & \multicolumn{2}{|l|}{ (1) } & \multicolumn{2}{|l|}{ (2) } \\
\hline & Revenue & Expenditure & Revenue & Expenditure \\
\hline \multirow[t]{2}{*}{ Error } & & $0.465^{* * *}$ & & $0.497^{* * *}$ \\
\hline & & $(0.0749)$ & & $(0.0844)$ \\
\hline \multirow[t]{2}{*}{ Revenue } & & $0.360^{* * *}$ & & $0.440^{* * *}$ \\
\hline & & $(0.0340)$ & & $(0.0531)$ \\
\hline \multirow[t]{2}{*}{ Revenue $(-1)$} & $0.950^{* * *}$ & & $1.139^{* * *}$ & \\
\hline & $(0.0460)$ & & $(0.0923)$ & \\
\hline \multirow[t]{2}{*}{ Expenditure } & 0.0510 & & -0.141 & \\
\hline & $(0.0477)$ & & $(0.0953)$ & \\
\hline \multirow[t]{2}{*}{ Expenditure $(-1)$} & & $0.653^{* * *}$ & & $0.554^{* * *}$ \\
\hline & & $(0.0345)$ & & $(0.0542)$ \\
\hline \multirow[t]{2}{*}{ Growth } & $27.16^{* * *}$ & $-13.70^{*}$ & $27.03^{* *}$ & $-18.90^{*}$ \\
\hline & (7.301) & $(6.881)$ & $(8.981)$ & $(7.516)$ \\
\hline \multirow[t]{2}{*}{ Unemployment } & $23.14^{*}$ & $18.58^{*}$ & $46.41^{* * *}$ & $27.66^{* * *}$ \\
\hline & $(9.375)$ & (7.559) & (14.04) & $(7.882)$ \\
\hline \multirow[t]{2}{*}{ Initiative } & 11.06 & 18.27 & 15.16 & 17.61 \\
\hline & $(13.52)$ & (12.33) & (15.09) & (11.72) \\
\hline \multirow[t]{2}{*}{ Referendum } & 1.013 & $-22.74^{*}$ & -1.952 & $23.18^{*}$ \\
\hline & $(12.04)$ & (11.06) & $(13.51)$ & $(10.67)$ \\
\hline \multirow[t]{2}{*}{ Concordance } & 0.831 & -1.416 & 0.733 & -1.251 \\
\hline & $(1.510)$ & (1.384) & $(1.756)$ & $(1.381)$ \\
\hline \multirow[t]{2}{*}{ Right-wing } & -1.535 & -1.027 & -1.721 & -0.866 \\
\hline & (1.039) & $(0.959)$ & $(1.215)$ & $(0.971)$ \\
\hline \multirow[t]{2}{*}{ Election } & 17.61 & 38.01 & 25.89 & 27.81 \\
\hline & (27.09) & (24.87) & $(31.52)$ & (24.84) \\
\hline \multirow[t]{2}{*}{ Coalition } & -12.28 & 16.16 & -8.232 & 19.49 \\
\hline & (17.29) & (15.98) & (20.02) & $(16.12)$ \\
\hline \multirow[t]{2}{*}{ Departments } & 1.263 & $12.75^{*}$ & 6.775 & $14.41^{* *}$ \\
\hline & $(5.927)$ & $(5.338)$ & (7.183) & $(5.376)$ \\
\hline \multirow[t]{2}{*}{ Elderly } & -0.0937 & 10.73 & 4.307 & 11.56 \\
\hline & (7.617) & $(6.885)$ & $(9.289)$ & (7.033) \\
\hline \multirow[t]{2}{*}{ Geneva } & 69.86 & $302.1^{* * *}$ & 207.7 & $344.8^{* * *}$ \\
\hline & (91.88) & (79.25) & (122.9) & $(83.42)$ \\
\hline \multirow[t]{2}{*}{ Intercept } & 70.44 & 71.04 & -15.96 & 1.971 \\
\hline & $(182.3)$ & $(168.4)$ & $(214.8)$ & $(171.4)$ \\
\hline$R^{2}$ & 0.9893 & 0.9916 & 0.9860 & 0.9917 \\
\hline Ftest (p-value) & 0.0000 & 0.0000 & 0.0000 & 0.0000 \\
\hline$N$ & 595 & 595 & 571 & 571 \\
\hline
\end{tabular}

Note: Parameter values appear without parentheses, and standard errors within. Asterisks denote the level of significance of parameter values : ${ }^{* * *}$ indicating significance at the $1 \%$ level, ${ }^{* *}$ at the $5 \%$ level, and ${ }^{*}$ at the $10 \%$ level. The F-test tests the null hypothesis that all coefficients are jointly equal to zero 
poses to test explicitly the potential relationship between tax revenue budgeting error and fiscal deficits. Referring to the Swiss context, we argue that underestimation of direct tax revenue reduces public deficits and that this effect is driven by a decrease in public expenditure. Using panel data for the 26 Swiss cantons over the 1980-2002 period, we first estimate a single equation model of fiscal deficit by two-stage least squares and show that tax revenue budgeting errors have a significant negative effect on fiscal balances (i.e., underestimation reduces deficits). Then we estimate a simultaneous equations model of revenue and expenditure by three-stage least squares and find a positive coefficient measuring the effect of tax revenue budgeting errors on expenditure (i.e., underestimation reduces expenditure). These econometric results confirm the hypothesis we sought to test, i.e., by reducing expenditure, underestimating tax revenue decreases fiscal deficits. Moreover, the effect on expenditure and deficit turns out to be symmetrical for underestimation and overestimation. Thus, this study provides evidence that prudent tax revenue budgeting not only reduces deficits but also supports the symmetrical argument that overestimating tax revenue creates additional deficit.

In general, however, we would not advocate deliberate underestimation of tax revenue as a policy tool to curb fiscal deficits. An important drawback of tax revenue underestimation is that it detracts resources from the democratic debate. Consequently, a risk exists that the use of these resources would not correspond to voters' fiscal preferences but rather to some budget officials' or elected politicians' personal interests. Indeed, politicians may be merely seeking to create a buffer in order to increase expenditure subsequently for re-election purposes (Bischoff and Gohout 2010; van der Ploeg 2010). Moreover, in some weak and corrupted institutional settings with poor checks and balances, underestimating tax revenue may even be a way for incumbent politicians and officers to conceal the extraction of resources from public budgets (Danninger 2005). Ideally, we would prefer to argue that the budgeted amount of tax revenue should equal tax revenue optimal forecast and explicit fiscal rules brought into law through a democratic process should be privileged in order to avoid deficits and to cope with economic uncertainty.

Nonetheless, when such explicit rules are lacking or their design turns out to be suboptimal, underestimating tax revenue may be an effective alternative way for policymakers to keep expenditure under control and to reduce deficits. But even in such a case, whether underestimating tax revenue is fiscally and/or economically desirable depends on the respective fiscal situation and economic environment of the public entities concerned-the Swiss cantons in our case. Fiscally, we can distinguish two clear-cut cases. On the one hand, in cantons with a relatively high level of public debt and persistent deficits, systematically underestimating tax revenue turns out to be a fiscally sound practice since it reduces the size of these deficits, and in consequence the rate of debt accumulation. On the other hand, in cantons with a relatively low level of public debt and persistent surpluses, it cannot be concluded that systematically underestimating tax revenue is fiscally sound. In these cantons, the low level of public debt is often due to a lack in long-term investment (typically infrastructure) needed to implement public policies. In this case, underestimating tax revenue contributes to the concealment of some resources that would be needed to support a higher rate of public investment and thereby a quicker catch-up with respect to other cantons. In 
the cases that are not clear-cut (high debt/surpluses and low debt/deficits), drawing conclusions is more fastidious since the creation of surpluses (deficits) may be optimal (without underestimating tax revenue) with respect to the current rate of debt accumulation in the canton. From the perspective of stabilization policy, underestimating tax revenue during periods of weak economic growth or recession could be harmful since it reduces expenditure that would be needed to increase global demand. Conversely, in a period of high economic activity, reducing public expenditure by underestimating tax revenue could be desirable since it may help to avoid economic overheating.

To conclude, it is important to remember that, even in the cases when underestimating tax revenue would be wise and desirable, conditions for its implementation might not be fulfilled. Consequently, it is necessary to know more about the determinants driving tax revenue budgeting errors. Recent studies have emphasized the important role of political determinants. In particular, Goeminne et al. have shown that large coalitions tend to be more cautious in their tax projections. Given the prevalence of large coalitions in Swiss cantons, we would not be surprised to find a similar effect. Some authors have also suggested, without testing it explicitly, that the finance minister may play a central role in the implementation of prudent tax revenue budgeting (Goeminne et al. 2008; van der Ploeg 2010). Given the characteristics of the budgeting process in Swiss cantons, we also tend to think that the finance minister may play a key role in the determination of tax revenue budgeting errors. Since such an investigation was not our goal, our estimations do not provide any evidence about these relationships in the Swiss context. Thus, the attempt to explain the variability of cantonal tax revenue budgeting errors by identifying their (political) determinants turns out to be a natural question to explore in future research.

\section{Appendix A: Revenue and expenditure: summary statistics}

Table 5 Cantonal revenue and expenditure in real CHF per capita over 1980-2002

\begin{tabular}{|c|c|c|c|c|c|c|c|c|}
\hline \multirow[t]{2}{*}{ Canton } & \multicolumn{4}{|l|}{ Revenue } & \multicolumn{4}{|c|}{ Expenditure } \\
\hline & Mean & sd & $\min$ & $\max$ & Mean & sd & $\min$ & $\max$ \\
\hline $\mathrm{AG}$ & 5015.384 & 710.5594 & 4087.634 & 6301.105 & 4977.300 & 746.4878 & 4099.783 & 6128.389 \\
\hline AI & 6735.898 & 941.486 & 5083.075 & 8253.094 & 6612.564 & 945.6279 & 5318.897 & 8541.548 \\
\hline $\mathrm{AR}$ & 5287.862 & 1200.143 & 3891.616 & 7203.918 & 5428.958 & 1095.988 & 3914.904 & 7233.634 \\
\hline $\mathrm{BE}$ & 6200.800 & 1088.415 & 4811.023 & 8368.874 & 6397.397 & 1080.012 & 4896.537 & 8411.978 \\
\hline $\mathrm{BL}$ & 6916.597 & 1152.641 & 5449.983 & 9107.365 & 6870.549 & 1163.477 & 5570.413 & 8919.044 \\
\hline BS & 15935.96 & 2145.625 & 13051.88 & 20734.09 & 16166.46 & 1998.802 & 13437.30 & 20296.12 \\
\hline FR & 6743.588 & 1076.687 & 5022.41 & 8510.944 & 6702.104 & 1220.859 & 4977.789 & 8433.949 \\
\hline GE & 12922.87 & 1614.766 & 10000.55 & 16080.99 & 13657.23 & 1597.303 & 10526.85 & 15876.66 \\
\hline GL & 7457.922 & 1025.488 & 5823.063 & 8921.749 & 7582.783 & 1251.027 & 5533.799 & 9494.221 \\
\hline
\end{tabular}


Table 5 (Continued)

\begin{tabular}{|c|c|c|c|c|c|c|c|c|}
\hline \multirow[t]{2}{*}{ Canton } & \multicolumn{4}{|l|}{ Revenue } & \multicolumn{4}{|l|}{ Expenditure } \\
\hline & Mean & $\mathrm{sd}$ & $\min$ & $\max$ & Mean & sd & $\min$ & $\max$ \\
\hline GR & 7171.030 & 1232.859 & 5538.316 & 9327.953 & 7159.871 & 1352.176 & 5480.771 & 9529.598 \\
\hline $\mathrm{JU}$ & 6673.068 & 1510.690 & 4434.991 & 9665.524 & 6942.820 & 1443.545 & 4589.529 & 9380.639 \\
\hline LU & 5455.992 & 1191.130 & 4063.364 & 7578.604 & 5559.637 & 1078.827 & 4140.649 & 7340.158 \\
\hline $\mathrm{NE}$ & 6539.801 & 1405.199 & 4498.059 & 8861.885 & 6784.474 & 1498.824 & 4488.560 & 8772.98 \\
\hline NW & 5249.295 & 1034.496 & 3557.105 & 8269.055 & 5218.062 & 1074.516 & 3290.795 & 7910.633 \\
\hline OW & 5582.069 & 1149.789 & 3937.727 & 7741.923 & 5614.803 & 1129.461 & 4014.742 & 7464.314 \\
\hline SG & 5236.472 & 1140.167 & 3739.511 & 7196.129 & 5246.776 & 1201.734 & 3673.273 & 7370.006 \\
\hline $\mathrm{SH}$ & 5776.799 & 1050.944 & 4541.584 & 7826.609 & 5754.933 & 1033.157 & 4459.804 & 7633.352 \\
\hline SO & 4835.597 & 733.8441 & 3867.085 & 6318.657 & 4913.816 & 776.6350 & 3942.69 & 6124.056 \\
\hline $\mathrm{SZ}$ & 4513.717 & 873.6606 & 3415.338 & 6127.334 & 4391.981 & 671.7830 & 3436.821 & 5972.051 \\
\hline TG & 4953.364 & 748.7518 & 4150.928 & 6347.234 & 5043.160 & 746.1833 & 4034.496 & 6081.947 \\
\hline $\mathrm{TI}$ & 6921.790 & 987.8556 & 5117.452 & 8206.998 & 6905.769 & 1051.988 & 5398.620 & 8213.416 \\
\hline UR & 7571.280 & 1308.656 & 5192.997 & 9087.474 & 7655.984 & 1342.850 & 5333.400 & 9453.874 \\
\hline VD & 7339.849 & 1073.150 & 5835.963 & 9634.512 & 7645.157 & 1161.993 & 5885.842 & 9991.569 \\
\hline VS & 5959.142 & 1003.294 & 4695.405 & 8176.016 & 6068.856 & 947.0116 & 4919.074 & 7728.980 \\
\hline $\mathrm{ZG}$ & 6323.445 & 1039.847 & 4528.51 & 8304.04 & 6236.517 & 1387.902 & 4143.831 & 8202.335 \\
\hline $\mathrm{ZH}$ & 6295.357 & 1023.407 & 5061.018 & 8329.325 & 6424.381 & 857.3253 & 5009.492 & 7980.288 \\
\hline All & 6754.421 & 2671.347 & 3415.338 & 20734.09 & 6844.705 & 2773.077 & 3290.795 & 20296.12 \\
\hline
\end{tabular}

\section{Appendix B: Control variables: summary statistics}

Table 6 Summary statistics of control variables

\begin{tabular}{llcccc}
\hline Variable & Unit/Domain & Min & Max & Mean & $\mathrm{Sd}$ \\
\hline Growth & $\%$ & -1.33 & 4.55 & 1.67 & 1.65 \\
Unemployment & $\%$ & 0.00 & 7.80 & 1.80 & 1.79 \\
Referendum & {$[0-6]$} & 0.00 & 6.00 & 3.96 & 1.32 \\
Initiative & {$[0-6]$} & 1.67 & 6.00 & 4.46 & 1.31 \\
Departments & $\mathrm{R}+$ & 5.00 & 13.0 & 7.66 & 2.33 \\
Coalition & $\mathrm{R}+$ & 1.00 & 5.00 & 3.31 & 0.92 \\
Right-wing & {$[0-100] \%$} & 33.3 & 100 & 78.3 & 16.0 \\
Concordance & {$[0-100] \%$} & 53.3 & 100 & 86.5 & 10.3 \\
Election year & 0 or 1 & 0.00 & 1.00 & 0.23 & 0.42 \\
Elderly & {$[0-100] \%$} & 10.3 & 21.0 & 14.6 & 2.10 \\
\hline & & & & &
\end{tabular}




\section{Appendix C: Tests for the symmetry of the effect of tax revenue budgeting errors}

Table 7 Tests of symmetry: test statistic and p-value

$H_{0}$ assumes the symmetry of the effect. $H_{0}$ can never be rejected

\begin{tabular}{lllllll}
\hline & \multicolumn{3}{l}{ Single equation } & & & \multicolumn{2}{l}{ Simultaneous equations } \\
& $(1)$ & $(2)$ & $(3)$ & & $(1)$ & $(2)$ \\
& GMM & 2SLS & 2SLS & 3SLS & 3SLS \\
\hline Chi2 & 0.01 & 0.01 & 0.05 & 0.47 & 0.44 \\
p-value & 0.933 & 0.932 & 0.8271 & 0.4919 & 0.4919 \\
\hline
\end{tabular}

\section{References}

Alesina, A., \& Perotti, R. (1995). The political economy of budget deficits. IMF Staff Papers 42, No.1.

Alesina, A., \& Perotti, R. (1999). Budget deficits and budget institutions. In J. M. Poterba \& J. von Hagen (Eds.), Fiscal institutions and fiscal performance (pp. 13-36). Chicago: Chicago Press for National Bureau of Economic Research.

Arellano, M., \& Bond, S. (1991). Some tests of specification for panel data: Monte Carlo evidence and an application to employment equations. Review of Economic Studies, 58, 277-297.

Arellano, M., \& Bover, O. (1995). Another look at the instrumental variable estimation of errorcomponents models. Journal of Econometrics, 68, 29-51.

Ashworth, J., Geys, B., \& Heyndels, B. (2005). Government weakness and local public debt development in Flemish municipalities. International Tax and Public Finance, 12(4), 395-422.

Auerbach, A. J. (1999). On the performance and use of government revenue forecasts. National Tax Journal, 52(4), 767-782.

Bischoff, I., \& Gohout, W. (2010). The political economy of tax projections. International Tax and Public Finance, 17, 133-150.

Blundell, R., \& Bond, S. (1998). Initial conditions and moment restrictions in dynamic panel data models. Journal of Econometrics, 87, 115-143.

Couture, J., \& Imbeau, L. M. (2009). Do governments manipulate their revenue forecasts? Budget speech and budget outcomes in the Canadian provinces, Studies in public choice (Vol. 9, pp. 155-166). Berlin: Springer.

Danninger, S., Cangiano, M., \& Kyobe, A. (2005). The political economy of revenue forecasting experience from low-income countries. IMF Working Paper 2 02, 30.

Feenberg, D. R., Gentry, W., Gilroy, D., \& Rosen, H. S. (1989). Testing rationality of state revenue forecasts. Review of Economics and Statistics, 71(2), 300-308.

Feld, L. P., \& Matsusaka, J. G. (2003). Budget referendums and government spending: evidence from swiss cantons. Journal of Public Economics, 87(12), 2703-2724.

Frey, B. S., \& Stutzer, A. (2005). Beyond outcomes: measuring procedural utility. Oxford Economic Papers, 57, 90-11.

Garand, J., \& Kapeluck, B. (2004). Understanding surpluses, deficits, and debt in the American states, 1950-1998. In L. Imbeau \& F. Petry (Eds.), Politics, institutions and fiscal policy: public deficits and surpluses in federated states (pp. 49-87). Lanham: Lexington Books.

Goeminne, S., Geys, B., \& Smolders, C. (2008). Political fragmentation and projected tax revenues: evidence from Flemish municipalities. International Tax and Public Finance, 15, 297-315.

Hayashi, F. (2000). Econometrics. Princeton: Princeton University Press.

Hibbs, D. (1987). The political economy of industrial democracy. Cambridge: Harvard University Press.

Joyce, P., \& Rodgers, R. (1996). The effect of underforecasting on the accuracy of revenue forecasts by state governments. Public Administration Review, 56(1), 48-56.

Kirchgässner, G., \& Pommerehne, W. (1997). Public spending in Federal States: a comparative econometric study. In Budgetary policy modelling: public expenditures (pp. 179-213). London: Routledge. 
Matsusaka, J. G. (1995). Fiscal effects of the voter initiative: evidence from last 30 years. Journal of Political Economy, 103, 587-623.

Mocan, H. N., \& Azad, S. (1995). Accuracy and rationality of state General Fund Revenue forecasts: evidence from panel data. International Journal of Forecasting, 11(3), 417-427.

Niskanen, W. A. (1971). Bureaucracy and representative government. Chicago: Aldine-Atherton.

Nordhaus, W. D. (1975). The political business cycle. Review of Economic Studies, 42(2), 169-190.

Persson, T., \& Svensson, L. E. O. (1989). Why a stubborn conservative would run a deficit. The Quarterly Journal of Economics, 104(2), 324-345.

Pinho, M. M. (2004). Political models of budget deficits: a literature review. University of Porto, Working Paper 138.

Pommerehne, W., Kirchgässner, G., \& Feld, L. (1996). Tax harmonization and tax competition at statelocal levels: lessons from Switzerland. In G. Pola, G. France, \& R. Levaggi (Eds.), Developments in local government finance: theory and policy (pp. 292-330). Cheltenham: Edward Elgar.

Poterba, J. M. (1996). Budget institutions and fiscal policy in the US States. American Economic Review, $86(2), 395-400$.

Roubini, N., \& Sachs, J. (1989). Political and economic determinants of budget deficits in the industrial democracies. European Economic Review, 33, 903-933.

Serritzlew, S. (2005). Breaking budgets: an empirical examination of danish municipalities. Financial Accountability \& Management, 21(4), 413-435.

van der Ploeg, F. (2010). Political economy of prudent budgetary policy. International Tax and Public Finance, 17, 295-314.

Velasco, A. (2000). Debts and deficits with fragmented fiscal policymaking. Journal of Public Economics, $76,105-125$.

von Hagen, J., \& Harden, I. (1995). Budget processes and commitment to fiscal discipline. European Economic Review, 39, 771-779.

Wehner, J. (2010). Cabinet structure and fiscal policy outcomes, European journal of political research. Comparative Political Studies, 43(2), 208-229. 